\title{
Effect of deoxynivalenol on humoral and cellular immune-responses to salmonella infection
}

\author{
Yoshiko Sugita-Konishi*1, Yukiko Hara-KUdO*1, Fumiko KaSUGA*1, \\ Masako YAMAMOTO*2 and Susumu KUMAGAI*1 \\ (Received Jun. 21, 1996; Accepted Oct. 1, 1996)
小西 良子*1, 工藤由起子*1, 春日 文子*1, 山本 雅子*2, 熊谷 進 ${ }^{* 1}:$ サルモネラ 感染に対する液性及び細胞性免疫防御へのデオキシニバレノールの影響

\begin{abstract}
Summary
Our previous work indicated that sequential exposure to a low concentration of deoxynivalenol (DON) increased the susceptibility of mice to salmonella via oral infection. In this study, the effect of DON on humoral and cellular immune defense against salmonella infection in the same conditions as the previous study was investigated. DON reduced the production of specific antibodies against salmonella and the delayed type (footpad) hypersensitivity (DTH) reaction to formalin-killed salmonella extract. These results demonstrate that the immunosuppresive effects of DON are involved in an increased susceptibility to salmonella infection.
\end{abstract}

Key words : DON, デオキシニバレノール ; Salmonella, サルモネラ ; IgM, イムノグロブリン M ; DTH，遅延型過敏反応

Salmonella enteritidis causes systemic typhoid fever in mice ${ }^{1)}$. Salmonella is classified as a facultative intracellular bacterium by virtue of its ability to survive and multiply within phagocyte cells of the hosts mononuclear phagocyte system ${ }^{2}$. They are known to induce both humoral and cell-mediated immune responses ${ }^{3)}$. In the humoral immune response, IgM anti-Salmonella antibodies appear in the serum in the very early phase of infection. The remarkable effect on IgM production has been postulated to be a special feature of salmonella infections ${ }^{4}$. However these antibodies were unable to inhibit the growth of salmonellae in the reticuloendothelial system (RES) ${ }^{3}$, and as a result, antibodies alone could not protect mice from salmonella infection $^{4}$. In the later phase of infection, cellmediated immune responses are crucial for immunity to many intracellular pathogens including salmonellae ${ }^{2)}$. $T$ cell mediated immunity is thought to be essential for the killing of the bacteria in the RES $^{5)}$.

Deoxynivalenol (DON) is known to possess immunosuppressive effects such as decreasing the lymphoblastogenic response and impairing of phagocytosis $^{6,7)}$. We found previously that sequentially exposing mice to relatively low doses of orally administered DON increased their susceptibility to salmonella infection ${ }^{8)}$. In this study, we investigated the effects of DON on the immune-defense responses to salmonella infection.

\section{Materials and Methods}

Balb/c male mice of 7 weeks of age purchased from the Shizuoka Laboratory Animal Center

${ }^{* 1}$ Department of Biomedical Food Research, National Institute of Health (1-23-1, Toyama, Shinjuku-ku, Tokyo 162)

国立予防衛生研究所 食品衛生微生物部（干162 東京都新宿区戸山 1-23-1）

*2 Department of Veterinary, Azabu University (1-17-71, Fuchinobe, Sagamihara-shi, Kanagawa 229)

麻布大学 獣医学部（干229 神奈川県相模原市淵野辺 1-17-71） 
(Shizuoka, Japan) were used.

Oral infection of mice was carried out with $S$. enteritidis (S.E., strain No. E930448) as previously described $^{8)}$. Briefly, mice were divided into 2 groups, the test group was given water containing 2 ppm of DON (Sigma Chemical Co., USA) and the control group was given toxin-free water for 3 weeks. Both groups were inoculated with $6 \times 10^{5} \mathrm{~S}$.E. cells in $0.2 \mathrm{ml}$ of phosphate-buffered saline (PBS) on day 14 . Serum and splenocytes were collected on day 3, 5 and 7 after inoculation. Splenocytes $\left(5 \times 10^{5}\right.$ cells $\left./ \mathrm{ml}\right)$ were cultured with lipopolysaccarides $(20 \mu \mathrm{g} / \mathrm{ml})$ for $48 \mathrm{~h}$ in $5 \% \mathrm{CO}_{2}$. The culture supernatant of the splenocytes was collected and frozen to $-80^{\circ} \mathrm{C}$ until used for the TNF- $\alpha$ assay.

The titer of anti-Salmonella IgM antibodies in the serum was measured by ELISA. Flat-bottomed 96 well microtiter plates were coated with formalintreated S.E. and a 10-fold dilution of serum sample was dispensed into each well. Bound specific IgM was detected by the addition of rabbit anti mouse IgM antibody-alkaline phosphatase conjugate (Zymed Laboratories Inc. USA). The assay was developed by the addition of p-nitrophenyl phosphate and read at $405 \mathrm{~nm}$. IFN- $\gamma$ in the serum and TNF- $\alpha$ in the culture supernatant derived from LPS. stimulated splenocytes were detected with Genzyme ELISA kits (Genzyme, USA). DTH was estimated by measuring footpad swelling. Five days after inoculation, $25 \mu 1$ of the formalin-treated S.E. in PBS was injected in the left hind footpad and PBS was injected in the right hind footpad as a control. Footpad thickness was measured $48 \mathrm{~h}$ after the injection, and readings were expressed as the mean thickness increase in $0.1 \mathrm{~mm}$ units (mean $\pm \mathrm{SE}$ ) in the injected footpads compared to the control footpads. All data was analyzed by the Student's $t$-test.

\section{Results and Discussion}

It is generally accepted that host defense against salmonellosis involves 2 different types of immunity, humoral and cell-mediated immunity. In the humoral response, specific IgM antibodies forms the major proportion of the primary response. Also, specific
IgM antibodies were reported to be more effective than IgG antibodies at promoting the clearance of bacteria from the blood ${ }^{4}$. In Fig. 1, the titer of anti-Salmonella IgM antibodies in the serum 3 days after inoculation was shown as the absorbance obtained in the ELISA. The titers of antiSalmonella IgM antibodies in the serum of the DONtreated group were significantly lower than that in the serum of the control group. Rasooly and Pestka found that DON induces the hyper-elevation of total and specific IgA in the serum and the down regulation of total and specific IgM and IgG during the oral exposure to $25 \mathrm{ppm}$ DON for 4 weeks ${ }^{9}$. Although the exposure method used in our study was differed from theirs, we found that even $2 \mathrm{ppm}$ of DON induced the down regulation of specific IgM. This down regulation is one reason why DON increases the susceptibility of mice to salmonella infection.

A crucial factor in the immune mechanisms to survive an infection caused by intracellular parasitic bacteria is the development of a cell-mediated immune response which arrests the bacteria population in the RES ${ }^{5}$. Several appproaches have been

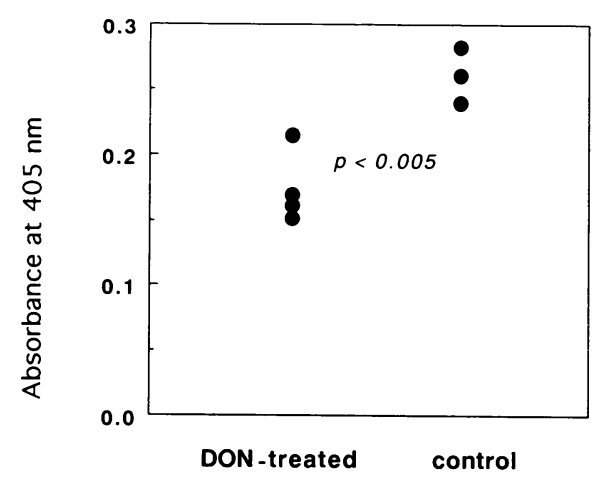

Fig. 1 Effect of DON on the production of antiSalmonella IgM following inoculation with Salmonella enteritidis.

Anti-Salmonella IgM in the serum obtained on 3 days after infection was measured by ELISA. The titers were expressed as absorbances at $405 \mathrm{~nm}$. The titers of anti-Salmonella IgM in the DON treated group were significantly different from those of the control group $(p<0.005)$. 


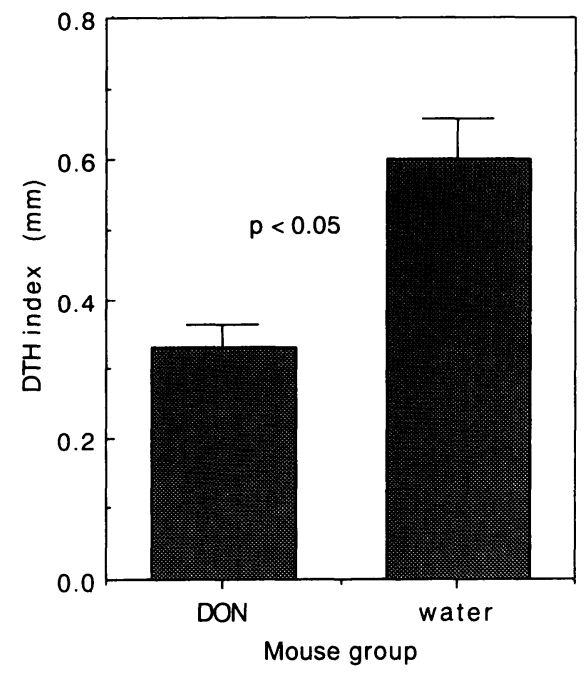

Fig. 2 Effect of DON on the DTH responses to salmonella following inoculation with Salmonella enteritidis.

DTH responses were measured via the footpad swelling response. Footpad thickness was measured $48 \mathrm{hr}$ after the injection of formalin-S. enteritidis on day 5 post-inoculation. The response of the DON treated group was significantly different from that of the control group $(p<0.05)$. DTH index : the difference in the footpad thickness between the antigen-and PBS-injected mice. All groups consisted of 5 mice.

used to investigate the role of specific cell-mediated immunity against salmonella infections. Delayed type hypersensitivity (DTH) reactions in response to salmonella antigens have been described in mice ${ }^{10-12)}$. In this study, the DTH reaction was used as an indicator for the development of cell-mediated immunity. Compared with the control group, DON-treated mice showed significantly lower $(p<0.05)$ DTH reactions (Fig. 2). The results indicated that DON inhibited the development of a cell-mediated immune response, and this explains why DON treated mice have an increase susceptibility to salmonella infection.

Recently it was reported that some kinds of $\mathrm{T}$ cell subclass and $\mathrm{T}$ cell cytokines, especially antitumor necrosis factor- $\alpha$ (TNF- $\alpha$ ) and interferron- $\gamma$ (IFN- $\gamma$ ) are involved in DTH ${ }^{13-16}$. To clarify the effects of
DON on the production of T cell cytokines, IFN- $\gamma$ in the serum and TNF- $\alpha$ in the culture supernatant obtained from infected splenocytes was measured. However, there were no significant differences in the production of $\mathrm{T}$ cell cytokines between the 2 groups (IFN- $\gamma$ on day 5 : control group, $25 \pm 5.2 \mathrm{U} / \mathrm{ml}$; DON treated group, $17 \pm 3.0 \mathrm{U} / \mathrm{ml}, n=5:$ TNF- $\alpha$ on day 3 : control group, $25 \pm 3.0 \mathrm{pg} / \mathrm{ml}$; DON treated group, $30 \pm 3.5 \mathrm{pg} / \mathrm{ml}, n=5$ ). Thus, the inhibition of the development of cell-mediated immune response caused by DON may be due to a reduction of the $T$ cell response, rather than reduced cytokine production.

Taken together, this study demonstrats that DON suppresses the production of specific IgM antibodies and inhibits the development of a cell-mediated response against salmonellae. The effects of DON may be largely concerned with the increased susceptibility of mice to S.E. infection.

\section{References}

1) Carter, P. B. : Infect. Immun., 10, 816 (1974).

2) Dunlap, N.E., Benjamin, W. H. Jr., McCall, R. D. Jr., Tilden, A. B., Briles. D. E.: Microbial Phathogen., 10, 297 (1991).

3) Hormaeche, C. E., Fahrenkrog, R. A., Pettifor. Q., Brock, J. : Immunology, 43, 547 (1981).

4) Saxen H.: J. Gen. Microbiol., 130, 2277 (1984).

5) Collins, F. M. : Bacteriol. Rev., 38, 371 (1974).

6) Robbana-Barbnat, S., Lafarge-frayssinet, C., Cohen, H., Neish, G. A., Frayssinet, C. : Toxicology, 48, 155 (1988).

7) Pier, A. C. : "Mycotoxins and Animal Foods", p. 489 (1986), CRC press, Boca Raton.

8) Kudo, Y., Sugita-Konishi, Y., Kasuga, F., Kumagai, S. : Mycotoxins, 42, 51 (1995).

9) Rasooly, L., Pestka, J. J. : Fd. Chem. Toxic., 30, 499 (1992).

10) Mastroeni, P., Villarreal-Pamos, B., Demarco de Hormaeche, D., Hormaeche, C. E. : Microbial Pathogen., 14, 369 (1993).

11) Killar, L. M., Eisenstein, T. K. : Infect. Immun., 52, 504 (1986).

12) Collins, F. M., Mackaness, G. B.: J. Immunol. 101, 830 (1968).

13) Mastroeni, P., Villarreal-Pamos, B., Hormaeche, C. E. : Microbial pathogen., 13, 477 (1992).

14) $\mathrm{Mu}$, H. H., Sewell, W. A. : Immunology, 83, 639 (1994). 
15) Matsui, K., Arai, T.: Microbiol. Immunol., 33, 699 (1989).

16) Higashi, N., Yoshizuka, N., Ohuchi, A., Osawa,
T., Kobayashi, Y.: Cell. Immunol., 161, 288 (1995) 